\title{
膀羘移行上皮癌に対する単純膀胱全摘除術の治療成績
}

$\begin{array}{ccccc} & \text { 西 } & \text { 尾 } & \text { 恭 } & \text { 規 } \\ \text { 国立がんセンター病院泌尿器科 } & \text { 松 } & \text { 本 } & \text { 恵 } & \text { 一 } \\ & \text { 大 } & \text { 谷 } & \text { 幹 } & \text { 伸 } \\ & \text { 垣 } & \text { 添 } & \text { 忠 } & \text { 生 }\end{array}$

\section{SIMPLE CYSTECTOMY FOR TRANSITIONAL CELL CARCINOMA OF THE BLADDER}

\author{
Yasunori Nishio, Keiichi Matsumoto, Mikinobu Ohtani and Tadao Kakizoe \\ Department of Urology, National Cancer Center Hospital, Tokyo
}

Sixty-two patients with the transitional cell carcinoma of the urinary bladder were treated by simple cystectomy without pelvic lymph nodes dissection at the department of Urology, National Cancer Center Hospital, Tokyo from 1962 to December, 1984.

Clinical staging proved accurate in 57 of 62 patients $(91.9 \%)$ and clinical grading proved accurate in 52 of 62 patients $(83.9 \%)$.

Two different types of intravesical ectopic reccurrences after bladder-preserving treatment were observed, i.e., rapidly growing, fulminant reccurrence and slowly growing reccurrence. Of 22 patients who had low grade (Grade 1-2) low stage (pTis-pT1) diseases treated by bladder-preserving methods previously, 3 patients $(13.6 \%)$ developed higher grade (Grade 3 ) tumors and only one $(4.5 \%)$ later developed invasive $(\geqq \mathrm{pT} 2)$ carcinoma.

The 5 -year survival rate according to pathological stage was $100 \%$ for 5 patients in pTis, $89.5 \%$ for 11 patients in pTa, $80.9 \%$ for 26 patients in pT $1,46.3 \%$ for 8 patients in pT 2 and $0 \%$ for 12 patients in pT3 and pT4. There was no significant difference between 5-year survival rate of patients with pTispT2 disease who were treated by simple cystectomy without pelvic lymph nodes dissection and that of patients with pTis-pT2 diseases who were treated by radical cystectomy with pelvic lymph nodes dissection, but the 5-year survival rates of patients with pT3 and pT4 disease treated by simple cystectomy was significantly lower than that of patients with pT3 and pT4 diseases treated by radical cystecomy.

要旨：1962年より1984年12月までの 22 年間に国立がんセンター病院泌尿器科で, 骨盤内リンパ節郭清術 を含まない単純膀胼全摘除術を施行した膀胖移行上皮癌症例62例の治療成績を検討した。

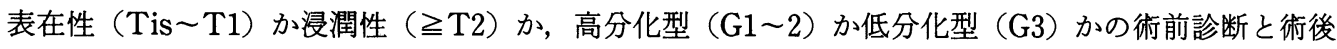
診断の正診率は，浸潤度診断で $91.9 \%$ ，悪性度診断で $83.9 \%$ あった。

膀胼保存療法後に再発をきたし, 単純膀胼全摘除術を施行した22症例の検討より, 膀胱異所性再発に は, (1)急速に膀脂略全面に再発をきたす場合, (2)少数個の腫瘍の発生からはじまり長期間を経て病変が 膀胱略全面に及ぶ場合の 2 つの異なる再発様式が存在すると考兄られた。 また, Low grade (Grade

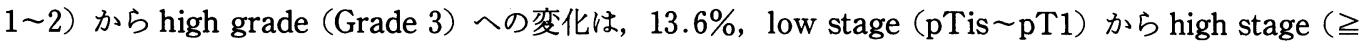

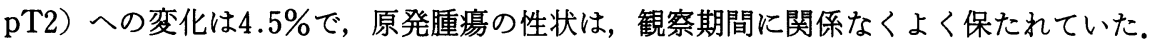

各浸潤度別実測 5 年生存率は, pTis 5 例 $100 \%$, pTa 11 例 $89.5 \%$, pT 126 例 $80.9 \%$, pT2 8 例 $46.3 \%$, pT3 \& pT4 12例 $0 \%$ で, 当センターで骨盤内リンパ節郭清術を含む根治的膀羘全摘除術を施行した症 例の生存率と比較し, pTis〜 pT2症例では有意差はなかった。 しかし, pT3, pT4症例では, 単純膀胼全 摘除術で有意に低かった。 以上の結果から，pTis〜 pT1までの表在性膀胼移行上皮癌症例では単純膀胱 
全摘除術で根治可能と考えられた。しかし，pT2以上の浸潤性症例では，骨盤内リンパ節郭清術を含む根 治性膀胱全摘除術が必要と考吕られた。

\section{緒言}

膀胱全摘除術は，表在性膀胼癌の多発症例および浸 潤性膀胼癌症例に対する最も確実な治療法として広く 施行されている。しかし，骨盤内リンパ節郭清術を同 時に施行すべきか否かについての定説はない.

当センターでは, 以前は膀胱全摘除術を施行する全 ての症例に骨盤内リンパ節郭清術を施行してきた。し かし，現在では，術前にTis〜T1までの表在性腫痬と 診断した症例には骨盤内リンパ節郭清術を含まない単 純膀脱全摘除術を，T2以上の浸潤性腫瘍と診断した症 例には，骨盤内リンパ節郭清術を含む根治的膀脱全摘 除術を施行することを原則としている．今回，単純膀 胼全摘除術を施行した膀胼移行上皮癌症例の治療成績 をまとめ, 骨盤内リンパ節郭清術の必要性, 単純膀脱 全摘除術の適応につき検討を加えたので報告する.

\section{対象および方法}

1962 年より 1984 年 12 月 31 日までの 22 年間に, 国立が んセンター病院泌尿器科で膀胱全摘除術を受けた症例 のらち，骨盤内リンパ節郭清術を施行しなかった膀胱 移行上皮癌症例62例を対象とした。

男子では，精のう腺, 前立腺および一部腹膜を含め 膀腌を摘出し, 女子では, 尿道全長就よび一部腹膜を 含め膀脱を摘出した。

病理学的検索 - 病期分類は, 泌尿器科 - 病理, 膀胱 癌取扱い規約1)にしたがった。

予後の算出の起点は, 膀胱全摘除術日とし, 1984年 12月31日現在の成績である。

\section{結果}

\section{1. 統計的事項}

対象症例62例の男女比は, 男47例, 女15例(男：女 $=$ $3.1: 1 ）$ で膀胱全摘除術時の年齢は, 31 歳から83歳, 平均61.6歳であった。

腫瘍の浸潤度は, pTis 5例, pTa 11例，pT1 26例， pT2 8 例, pT3 3例, pT4 9 例で, 腫瘍の悪性度は, Grade 14 例, Grade 2 27例, Grade 3 31例であった。

2. 手術適応, 術前診断と病理学的診断

当センターでは, 膀胼移行上皮癌症例を, 尿細胞診, 排泄性腎孟造影, 膀胱鏡所見, 腰麻下の双手診, TUR 招よび Multiple random punch biopsyを中心に，以 下の 3 つの type に分類し治療方針をたてている.

1）表在性（Tis〜T1），高分化型（G1２）で長期間
表在性にとどまると予想される症例

2）表在性である（Tis〜T1）が, 低分化型 (G3) で 浸潤性腫瘍の早期癌と判断される症例

3）浸潤性腫瘍（ $\geqq \mathrm{T} 2 ）$ 症例

1) type の症例に対しては, 膀脱保存療法を第 1 選 択とするが，TURを中心とする膀胱保存療法で control できないと判断した多発症例では単純膀胱全摘除 術を施行している.2)の type の症例では, 単純膀脱全 摘除術を施行ている. 3)の浸潤性腫瘍症例では骨盤内 リンパ節郭清術を含む根治的膀胱全摘除術を第 1 選択 としている。しかし，骨盤内リンパ節郭清術を施行し えないと判断した全身状態不良の症例では palliative operation として単純膀胼全摘除術を採用している. すなわち, 当センターでは, 単純膀胱全摘除術の適応 は，1）表在性, 高分化型腫瘍であるが, TURを中心 とする膀胼保存療法では control できないと判断した 症例，2）表在性であるが, 低分化型で浸潤性腫瘍の早 期癌と判断した症例，3）浸潤性腫瘍で, 骨盤内リンパ 節郭清術を含む根治的膀胱全摘除術が施行しえないと 判断した症例である.

今回の62例の手術適応による分類は，1）表在性, 高 分化型腫瘍で, 膀脱保存療法で control できないと判

Table 1 62例の Grade と Stage の関係

\begin{tabular}{ccccc}
\hline \multirow{2}{*}{ Stage $(P)$} & No. of Cases & \multicolumn{3}{c}{ Grade } \\
\cline { 2 - 5 } & 1 & 2 & 3 \\
\hline Tis & 5 & - & 2 & 3 \\
$\mathrm{Ta}$ & 11 & 3 & 8 & - \\
$\mathrm{T} 1$ & 26 & 1 & 13 & 12 \\
$\mathrm{~T} 2$ & 8 & - & 2 & 6 \\
$\mathrm{~T} 3$ & 3 & - & - & 3 \\
$\mathrm{~T} 4$ & 9 & - & 2 & 7 \\
\hline Total & 62 & 4 & 27 & 31
\end{tabular}

Table 2 手術適応，術前診断と術後診断

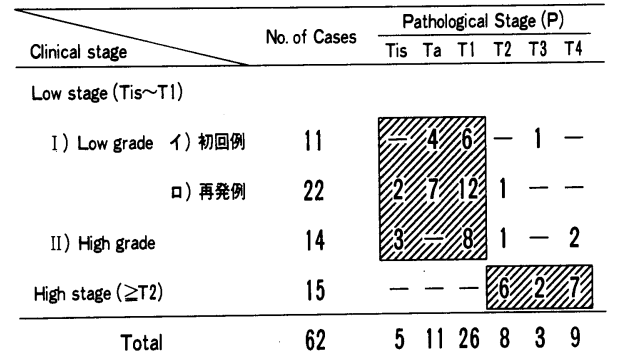


断した症例33例，らち初回治療症例11例，膀脱保存療 法後の膀胼内再発症例22例，2）表在性であるが，低分 化型で浸潤性腫瘍と判断した症例14例，3）浸潤性腫瘍 で palliative operation として単純膀脱全摘除術を採 用した症例15例であった（Table 2)。浸潤性腫瘍で,

骨盤内リンパ節郭清術を施行しえないと判断した15例 の主原因は，年齢（75歳以上） 6 例，糖尿病 3 例，心 筋梗塞の既往 3 例, 重複癌（食道癌, 肺癌） 2 例, 肺 結核 1 例であった。

術前診断で Tis〜 T1までの表在性腫瘍と診断した 47例の術後診断は, pTis 5 例, pTa 11例, pT126例, pT2 2 例, pT3 1 例, pT4 2 例で，術前診断で T2以 上の浸潤性腫瘍と診断した15例の術後診断は, pT2 6 例，pT3 2 例，pT4 7 例で，全体の術前浸潤度診断の 正診断は，62例中57例（91.9\%）であった。術前診断 に誤りのあった 5 例は，Tis と診断し，pT2であった 2 例, 膀胱䅡部に発生し, 尿道腫瘍との鑑別が困難であっ た女性の $\mathrm{pT} 3$ 症例 1 例，T1と診断したが，前立腺への 浸潤を認めた $\mathrm{pT} 4 \mathrm{a}$ 症例 2 例であった。

また, 悪性度の診断では, 術前に Low grade (Grade 1２）と診断した33例の術後診断は Grade 1 2 27例, Grade 36 例，術前に Grade 3 と診断した29例の術前 診断は, Grade 24 例, Grade 325 例で, 全体の術前 悪性度正診率は62例中52例（83.9\%）であった。悪性 度診断に誤りのあった10例はいずれも多発症例で, 術 前の biopsy と全摘標本の病理検索で差は認めた症例 であった。

3. 膀胼保存療法後の再発症例の膀脱全摘除術に至 るまでの経過拈よび病理学的変化

対象症例62例中, 表在性, 高分化型腫瘍と診断し, 膀胼保存療法後に，再発をきたした症例は22例であっ た (Table 3).

22例の初回治療は, TUR が14例と最も多く, 次いで TUR+放射線療法 3 例, TUR+持続動注 3 例, 術中照 射 ${ }^{2} 2$ 例であった。

治療回数は，1回が14例と最も多く,ついで 2 回 4 例, 3 回 3 例, 4 回 1 例であった.

初回治療から全摘除術までの期間は, 1 年以内 1 例, $1 \sim 2$ 年10例， $2 \sim 5$ 年 2 例， 5 年以上 9 例と, 2 年 以内に全摘除術を施行した症例と， 5 年以上を経てか ら全摘除術を施行した症例とに大別された。

初回治療時と全摘除術時の病理学的変化の検討で は, Grade が変化した症例 5 例, Stage が変化した症例 9 例であった. Grade の变化した 5 例は，G2 $\rightarrow \mathrm{G} 1$ へ
Table 3 膀胱保存療法後に再発をきたし全摘除術を 施行した22例の経過および病理学的変化

\begin{tabular}{|c|c|c|c|c|c|c|}
\hline Case $\frac{\text { 初回治 }}{\text { 治淩法. Sta }}$ & & Grad & 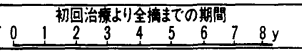 & $\begin{array}{l}\text { 治棈 } \\
\text { 回数 }\end{array}$ & $\frac{\text { 金捅 }}{\operatorname{Stage}(P)}$ & Grade \\
\hline 1 TUR & $\mathrm{Ta}$ & GI & $\infty$ & 1 & $\mathrm{Ta}$ & G1 \\
\hline 211 & $\mathrm{TI}$ & G2 & $\infty$ & 1 & $\mathrm{TH}$ & G3 \\
\hline 311 & $\mathrm{Ta}$ & GI & $\infty$ & 1 & $\mathrm{Ta}$ & G2 \\
\hline $4 \prime \prime$ & $\mathrm{Ta}$ & G2 & $\infty$ & 1 & $T / b$ & G2 \\
\hline 511 & $\mathrm{TI}$ & G2 & $\infty$ & 1 & $\mathrm{TI}$ & G2 \\
\hline 6 TUR+RT*1 & $\mathrm{TI}$ & G2 & 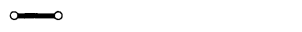 & 2 & $\mathrm{TI}$ & G2 \\
\hline 7 TUR & $\mathrm{TI}$ & G2 & $\infty$ & 1 & $\mathrm{~T} 2$ & G3 \\
\hline 8 術中照射 & $\mathrm{TI}$ & G2 & & 1 & $T 1 b$ & G2 \\
\hline 911 & $\mathrm{TI}$ & G2 & 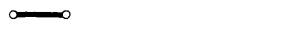 & 1 & Tla & G3 \\
\hline 10 TUR & $\mathrm{Ta}$ & G2 & 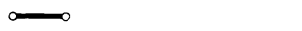 & 1 & $\mathrm{~T} 1$ & G2 \\
\hline 1111 & $\mathrm{Ta}$ & G2 & & 1 & $\mathrm{Ta}$ & G2 \\
\hline $12 " 1$ & $\mathrm{Ta}$ & G2 & & 1 & $\mathrm{Ta}$ & G2 \\
\hline $13 "$ & $\mathrm{TI}$ & G2 & & 1 & $\mathrm{~T} 1$ & G2 \\
\hline $14 " \prime$ & $\mathrm{TI}$ & G2 & & 1 & $\mathrm{Ta}$ & G1 \\
\hline $15 " 1$ & $\mathrm{Ta}$ & G2 & & 2 & $\mathrm{~T} 1$ & G2 \\
\hline 16 TUR+動注*2 & $\mathrm{Ta}$ & G2 & & 2 & $T 1$ & G2 \\
\hline 17 TUR & $\mathrm{TI}$ & G2 & & 3 & $\mathrm{TI}$ & G2 \\
\hline 18 TUR+動注*2 & $\mathrm{Ta}$ & G2 & $8 y^{859 M}$ & 3 & Tis & G2 \\
\hline 1911 & $\mathrm{Ta}$ & G2 & א. & 3 & $\mathrm{TI}$ & G2 \\
\hline 20 TUR & $\mathrm{Ta}$ & G2 & $11155 \mathrm{M}$ & 4 & $\mathrm{Ta}$ & G2 \\
\hline 21 TUR & $\mathrm{Ta}$ & G2 & $x_{0}^{12 y}$ & 1 & Tis & G2 \\
\hline 22 TUR+RT $^{* 1}$ & $\mathrm{Ta}$ & G2 & 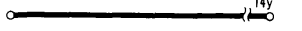 & 2 & $\mathrm{Ta}$ & G2 \\
\hline
\end{tabular}

$\mathrm{RT}^{* 1}$ : Radiation

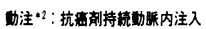

Grade down した症例1例，G1 $\rightarrow$ G2 1 例，G2 $\rightarrow$ G3 3 例と Grade up した症例 4 例であった. Stage の变化 した症例 9 例は, pTa $\rightarrow$ pTis 2 例, pT $1 \rightarrow \mathrm{pTa} 1$ 例 と 3 例が stage down したが， 6 例は pTa $\rightarrow$ pT 15 例, pT $1 \rightarrow$ pT2 1 例と stage-up した. しかし, 観察期 間 1 年 6 カ月で $\mathrm{pT} 1 \rightarrow \mathrm{pT} 2$ に変化した 1 例を除き, stage の変化は観察期間にかかわらず pTis〜pT1内の 変化であった。

4. 予後

1) 浸潤度別実測生存率 (Fig. 1)

62 例の浸潤度別 5 年実測生存率は, pTis 5 例 $100 \%$, pTa 11 例 $89.5 \%$, pT1 26 例 $80.9 \%$, pT2 8 例 $46.3 \%$, pT3 3 例 $0 \%$, pT4 9 例 $0 \%$ あったた。一方, 1962年 より1984年12月までの期間に当センターで骨盤内リン パ節郭清術を含む根治的膀脱全摘除術を施行した136 例の浸潤度別 5 年実測生存率は, pTis 5 例 $100 \%, \mathrm{pTa}$ 21 例 $72.2 \%$, pT1 43例79.6\%, pT2 16例 $39.5 \%$, pT3 28 例 $35.8 \%, \mathrm{pT} 425$ 例 $25.9 \%$ で, pTis〜pT2までの stage では両者に生存率の差を認めなかったが, pT3， pT4の stage では，骨盤内リンパ節郭清術を含む根治 的膀胖全摘除術を施行した症例の方が有意に生存率は 高かった。 
Fig. 1 浸潤度別実測生存率 : Radical cystectomy と Simple cystectomy の比較

Simple cystectomy

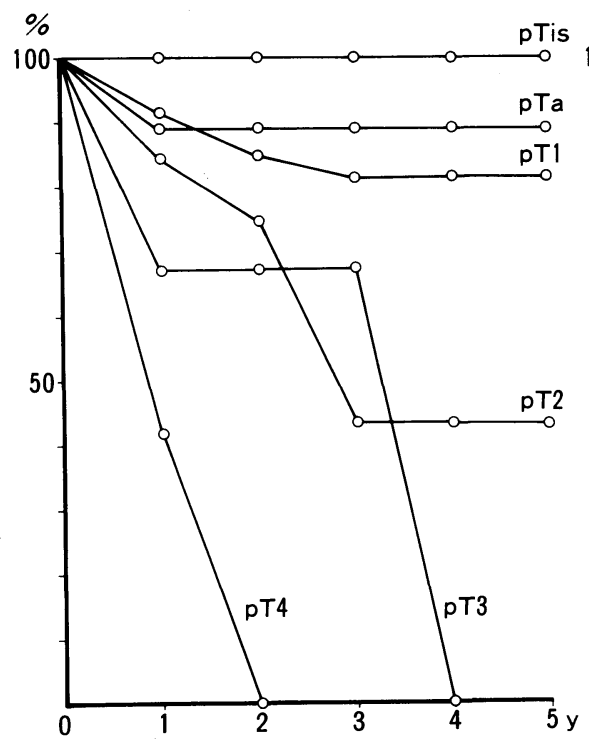

Radical cystectomy

2）死因抽よび尿道再発について

62例中37例が No evidence of disease で生存中であ ク，25例が死亡した．25例の死因は，5 例が手術死， 11例が他病死，9例が癌死であった (Table 4). 62例 を pTis〜 pT1の Low stage 群と pT2以上の high stage 群で検討すると, Low stage 群42例中癌死した 症例は 1 例 $(2.3 \%)$ のみで, 再発部位は, 多発性肺転 移で, 骨盤内再発を認めなかった. High stage 群20例 では， 8 例が癌死し，再発部位は 1 例が尿道再発によ る全身化， 7 例が骨盤内再発十遠隔転移であった。

尿道全摘除術を施行しなかった男子症例 45 例中 7 例 (15.6\%)に尿道再発を認め, そのらち 1 例は尿道再発 が初発再発部位で全身転移により死亡した。残る 6 例 は尿道全摘除術を施行, 再発の徴候を認めていない。

\section{考察}

膀胼移行上皮癌症例に対する治療法は，大さく膀胱 保存療法之膀胼全摘除術に大別され，表在性腫瘍に対 しては, 膀胼保存療法が, 浸潤性腫瘍に対しては膀胱 全摘除術が第 1 選択であるとされている.しかし, 種々 の膀脱保存療法後の膀胱内異所性再発率は60 70\%で あると報告3)4)され，膀胼保存療法で control でさない 症例や, 初猃時すでに多発で膀胱保存療法で治癒が期 待でさない症例では，膀胼全摘除術の適応とされてい る. しかし, 膀胼全摘除術を施行する際, 骨盤内リン パ節郭清術を施行すべきか否かに関しては，定説はな

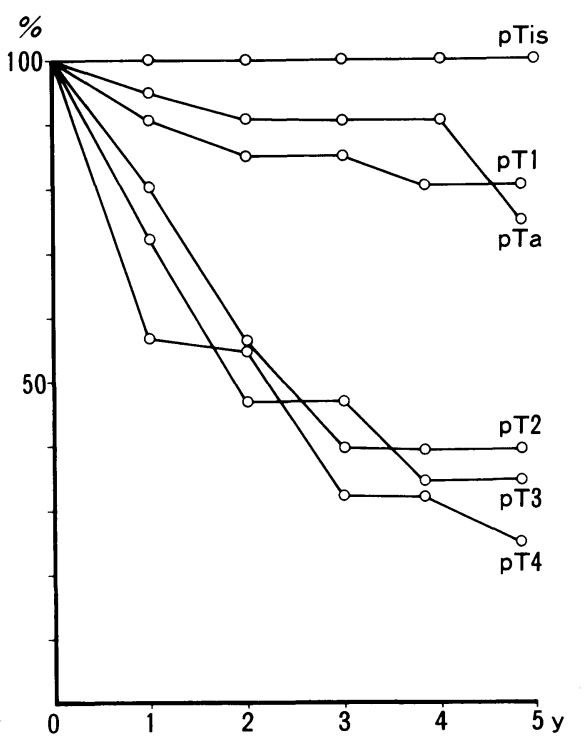

Table 4 62例の浸潤度別予後

\begin{tabular}{cccccc}
\hline \multirow{2}{*}{ Stage $(P)$} & No. of Cases & NED* & \multicolumn{4}{c}{ Dead } \\
\cline { 4 - 6 } Tis & 5 & 5 & - & - & - \\
Ta & 11 & 9 & 1 & 1 & - \\
T1 & 26 & 18 & 2 & 5 & 1 \\
\hdashline T2 & 8 & 2 & - & 4 & 2 \\
T3 & 3 & 1 & - & - & 2 \\
T4 & 9 & 2 & 2 & 1 & 4 \\
\hline Total & 62 & 37 & 5 & 11 & 9 \\
NED* : alive with no evidence of disease & &
\end{tabular}

い.

当センターでは, 膀胱移行上皮癌症例を, 臨床経過, 尿細胞診, 膀胱鏡所見, 腰麻下の双手診, TUR および Multiple punch biopsy で得られた病理学的所見を中 心に，前述した如く $3 つ の$ 異なった治療法を採用して いる. 1）Tis〜T1の表在性で，かつ G1 2の高分化腫 瘍で，長期間にわたり Low stage, Low grade にとど まると予想される症例に対しては，膀羘保存療法を第 1 選択とし，TURを中心とする治療をおこなってい る。しかし, 初診時すでに発多性で膀脱保存療法で control できないと判断した症例や，膀胱保存療法後 に再発をさたし, 膀胱保存療法で治癒できないと判断 した症例には，骨盤内リンパ節郭清術を含まない単純 膀胼全摘除術を施行している.2) Tis〜T1の表在性で 
あるが G3で浸潤性腫瘍に移行すると予想される症例 に対しては，浸潤癌の早期癌と考光，骨盤内リンパ節 郭清術を含まない単純膀胼全摘除術を第 1 選択として いる.3）T2以上の浸潤性腫瘍症例に対しては, 骨盤内 リンパ節郭清術を含む根治的膀胱全摘除術を第 1 選択 としている.しかし, 全身状態から判断し, palliative operation として，骨盤内リンパ節郭清術を含まない 単純膀脱全摘除術を採用することもある。

今回の集計の62例を術前診断と手術適応の面から検 討すると, (1)表在性高分化腫瘍で膀脱保存療法で control できないと判断した症例33例，(2浸潤癌の早期癌 と判断した症例14例, (3)浸潤癌で palliative operation として単純膀胱全摘除術を施行した症例15例で, 表在 性腫瘍が47例を占めた。術前診断の表在性腫瘍（Tis ～T1）と浸潤性腫瘍（ $\geqq \mathrm{T} 2 ）$, 高分化腫瘍 (G1 2) と 低分化腫瘍（G3）の鑑別には，膀胱鏡所見 ${ }^{5) 6}$ ，TUR, Multiple punch biopsyによる所見を最も重視してい るが, Tis〜 T1とミT2以上の診断の正診率は，62例中 57 例 (91.9\%), 高分化型腫瘍 $(\mathrm{G} 1 \sim \mathrm{G} 2)$ と低分化型 腫瘍 (G3) の診断の正診率は，62例中52例 (83.9\%) であり，膀胱鏡所見と生検にて，80\%以上の症例で, 表在性腫瘍が浸潤性腫瘍か, 高分化腫瘍か低分化腫瘍 かの鑑別診断は術前に可能と考えられた。

表在性でかつ高分化型の膀胱移行上皮癌症例に対し ては, 膀脱保存療法を第 1 選択としているが, 初診時 すでに多発性で，膀胱保存療法で治療できないと考兄 られる症例や，膀胼保存療法後に多発性の再発をきた 乙膀胼保存療法では治癒できない症例では, 単純膀胱 全摘除術を施行していることは前述したが，今回の集 計のらち, 表在性高分化腫瘍と術前診断した症例は, 33例であり, 初回治療として膀胼全摘除術を施行した 症例11例, 膀胼保存療法後の再発症例22例であった。 再発症例を初回治療より膀胱全摘除術までの期間で検 討すると，22例中 11 例（50\%）は 2 年以内に膀脱全摘 除術を施行した。しかし， 5 年以上経過してから膀羘 全摘除術を施行した症例も 9 例 (40.1\%) あり, 膀胼 全摘除術に至るまでの期間で 2 つの Group に大別さ れた. Bracken らは7)臨床的に表在性でかつ, TUR で controできないと診断した109例の膀胖移行上皮癌症 例に対し，骨盤内リンパ節郭清術を施行しない膀羘全 摘除術の治療成績を報告しているが，109例の平均 TUR の回数は 2 回であり, 10 回以上の TUR を受けた 症例は $10 \%$ 以下であったとし, 膀胱全摘除術が必要と なる症例では，短期間に TUR で control できない再
発を括こしていると述べている，今回の集計で，膀胱 保存療法後の再発症例を検討すると, 2 年以内に TUR で control できない再発をきたした症例が50\% と半数を占めていたが, 5 年以上の長期間を経て, 徐々 に膀胱全体に病変が広がっていく症例も40\%を占め, 膀脱保存療法後の膀胱内再発には, 1) 急速に膀胱の略 全面に再発をきたす場合, 2) 少数個の腫瘍の発生から はじまり，長時間を経て徐々に病変が膀羘略全面に及 ぶ場合の $2 つ の$ 異なった再発様式が存在すると考えら れた。

表在性高分化腫瘍に膀胼保存療法を続けていくうち に, 腫瘍の grade, stage が進行していく症例があると いわれている8). Barnes らは99TURにて治療を続けて いる再発性膀腅腫瘍114例の grade おょび stage の変 化を 5 年以上の観察で調查し，22例 (19\%) で, grade の上昇を認め，25例 (22\%)で， stage の上昇を認めた と報告している。また， Richie らは ${ }^{10)}$ grade の高い腫 瘍は, stage も進行する可能性が高いとしている.今回 の集計中, 膀胼保存療法後の再発例22例では, grade が 変化した症例 5 例, stage が変化した症例 9 例であっ た. Grade の変化は, G1 2内の変化が 2 例, G2 $\rightarrow \mathrm{G} 3$ 3 例で, low grade から high grade への変化は22例中 3 例 (13.6\%)であった. 又, stage の变化した 9 例中 8 例は pTis pT1の low stage 内での変化であり, 1 例が pT1 $\rightarrow$ pT2の変化であった. Low stage から high stage への変化は22例中 1 例 (4.5\%)にすぎなかった. 又, 5 年以上観察した 9 例の grade, stage の変化はい ずれも pTis〜 pT1, G1〜G2内の变化であり，膀胱移行 上皮癌症例の腫瘍の性状は, 長期間に及んでも变化す ることはまれであると考えられた。

骨盤内リンパ節郭清術については, 当センターでも, 以前は全症例に対し, 骨盤内リンパ節郭清術を施行し ていた．腫瘍の浸潤度とリンパ節転移率の関係につい て, Smith らは11) pTis $2 \%$, pT1 1\%, pT2 $8 \%$, pT3 47\%, pT4 42\% と報告, Skinner らは ${ }^{12)}$ pTis \& pTI $5 \%$, pT2 30\%, pT3a 31\%, pT3b $64 \%$, pT4 $50 \%$ と報告, pT 1 をでの症例で $5 \%$ 以下に対し $\mathrm{pT} 2$ 以 上の症例では stage の進行とともに転移率が高くなる ことを報告している，当センターに拈ける1962年より 1984年12月までの集計では, 膀胱移行上皮癌症例136例 中29例に骨盤内リンパ節転移を認め, 浸潤度との関係 は, pTis \& pTa $0 \%(0 / 26)$, pT1 4.7\% (2/43), pT2 19\% (3/16), pT3 32\% (9/28), pT4 65\% (15/ 23）であった. pTis〜pT1までの69例のリンパ節転移 
率が2.9\% (2/69) であり，69例中癌死した 5 例の再発 様式の検討で，骨盤内再発はリンパ節転移を有した 1 例1.4\%にすぎなかったことより, 現在では術前に T1 までの表在性腫瘍と診断した症例には，骨盤内リンパ 節郭清術を施行していない，今回の集計は，骨盤内リ ンパ節郭清術を施行しない単純膀羘全摘除術の集計で ある. 今回の集計62例中, pTis pT1までの表在性腫 瘍症例は，42例で，そのうち, 癌死した症例は 1 例, 再発形式は，肺の多発性転移で骨盤内再発を認めな かった，又，当センターで骨盤内リンパ節郭清術を施 行した根治的膀胼全摘除術の浸潤度別実測 5 年生存率 が, pTis 5 例 $100 \%$, pTa 21 例 $72.2 \%$, pT1 43 例 $79.6 \%$ に対し, 単純膀胼全摘除術では, pTis 5 例 $100 \%, \mathrm{pTa}$ 11例 $89.5 \%$, pT1 26例 $80.9 \%$ と, pTis〜pT1までの low stage 群では両者において差を認めなかった。以 上のことょり，今回の集計の検討から，術前に確実に T1までにとどまると診断できる症例に対しては，骨盤 内リンパ節郭清術は不要と考えられた。

pTis p p 1 ‡での表在性膀胼移行上皮癌症例の予後 は, 種々の治療法に扣いて良好であり, 膀脱保存療法 で膀胱内異所性再発率をいかに低下させるかが最大の 問題である。しかし，膀胱機能保存に力点をおくあま りに, 膀脱全摘除術の時期を逸してはならないし, 又, stage や gradeを upさせるような治療法を施行すべ きではないと考兄られる，今回の集計で, pTis〜 pT1 までの表在性腫瘍症例42例の手術死亡率は7.1\%（3/ $42)$, 実測 5 年生存率は $85.6 \%$, 癌死は 1 例 (2.4\%), であった.すなわち，表在性膀胱移行上皮癌症例では， 骨盤内リンパ節郭清術を含まない単純膀胱全摘除術を 施行すれば，ほぼ全例再発はなく治癒が期待できると いえる。

$\mathrm{pT} 2$ 以上の浸潤性膀胼移行上皮癌症例に対しては, 今回の集計で骨盤内リンパ節郭清術を含まない単純膀 脱全摘除術の実測 5 年生存率が pT2 8 例 $46.3 \%$, pT3 \&pT4 12例 $0 \%$ と, 根治的膀胱全摘除術の実測 5 年生存率 pT2 16 例 $39.5 \%, \mathrm{pT} 328$ 例 $35.8 \%, \mathrm{pT} 425$ 例 $25.9 \%$ に対し, pT $3, \mathrm{pT} 4$ 症例で有意に低いこと, お よびリンパ節転移率の高さから, 骨盤内リンパ節郭清 術を含む根治的膀羘全摘除術を第 1 選択とすべきであ り, 単純膀羘全摘除術はあくまで palliative operation にすぎないと考えられた。

\section{結語}

骨盤内リンパ節郭清術を含まない単純膀胼全摘除術 を施行した膀胱移行上皮癌症例62例の治療成績を検討
し，以下の結論を得た。

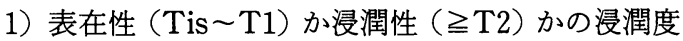
扣よび高分化型（G1２）低分化型（G3）かの悪性 度の術前診断と術後診断の正診率は, 浸潤度診断で 91.9\%，悪性度診断で83.9\%であった。

2）膀脱保存療法後に再発をきたし, 単純膀胼全摘除 術を施行した症例の検討より, 膀胱異所性再発には, (1)急速に膀羘略全面に再発をきたす場合, (2)少数個の 腫瘍の発生からはじまり，長期間を経て病変が膀胱略 全面に及ぶ場合の 2 つの異なる再発様式が存在すると 考兄られた。 また, low grade (G1 2)から high grade （G3）への変化は13.6\%, low stage (pTis〜 Tp1) か ら high stage（ $\geqq \mathrm{T} 2)$ への変化は $4.5 \%$ で膀胀移行上 皮癌症例の腫瘍の性状は, 期間に関係なくょく保たれ ていると考号れた。

3）各浸潤度別実測 5 年生存率は, pTis $100 \%, \mathrm{pTa}$ 89.5\%, pT1 $80.9 \%$, pT2 46.3\%, pT3 \& pT4 0\% で，当センターで骨盤内リンパ節郭清術を含む根治的 膀胼全摘除術と比較し, $\mathrm{pT}$ Tis〜 pT2で有意差はなかっ たが, pT3, pT4では単純膀胼全摘除術群で有意に生存 率は低かった。

4）pTis〜pT1までの表在性移行上皮癌症例では単 純膀胼全摘除術で根治可能と考兄られた. しかし, pT2 以上の浸潤性症例では骨盤内リンパ節郭清術を含む根 治的膀胼全摘除術が必要と考兄られた。

\section{文献}

1) 日本泌尿器科学会, 日本病理学会編：泌尿器科・病 理, 膀脱癌取扱い規約, 第 1 版, 金原出版, 東京, 1980.

2) Matsumoto, K., Kakizoe, T., Mikuriya, S., Tanaka, T., Kondo, I. and Umegaki, Y.: Clinical evaluation of intraoperative radiotherapy for carcinoma of the urinary bladder. Cancer, 47, 509-513, 1981.

3）丸 彰夫, 辻 一郎, 斯波光生, 大橋伸夫, 藤波順 一郎, 大室 博, 川倉宏一, 西田 亨, 草階佑幸, 大塚 晃, 網野 勇, 阿部弥理, 佐藤昭策, 南 茂 正, 鶴田 敦： 5 年以上経過した表在性膀羘腫瘍 症例の分析. 日泌尿会誌，74，799-807， 1983.

4) Barnes, R.W., Bengman, R.T., Hadley, H.L. and Love, D. : Control of bladder tumors by endoscopic surgery. J. Urol., 97, 864-869, 1967.

5）松本恵一：膀胱癌の内視鏡診断. 癌治療 - 今日之明 日, 2, 19-22, 1980.

6) Matsumoto, K. and Seto, T.: Estimation of prognosis of bladder cancer as based on serial endoscopic examinations and biposies. XIX 
Congress Societe Internationale D'Urologie, San Francisco September 5-10, 1982.

7) Bracken, R.B., McDonald, M.W. and Johnson, D.E. : Cystectomy for superficial bladder cancer. Urology, 18, 459-463, 1981.

8) Gilbert, H.A., Logan, J.L., Kagan, A.R., Friedman, H.A., Cove, J.K., Fox, M., Friedman, H.A., Lonni, Y.W., Rowe, J.H., Cooper, J.F., Nussbaum, H., Chan, P., Rao, A. and Starr, A. : The natural history of papillary transitional cell carcinoma of the bladder and its treatment in an unselected population on the bases of histologic grading. J. Urol., 119, 488-492, 1978.

9) Barnes, R., Hadley, H., Dick, A., Johnson, O. and Dexter, J. : Changes in grade and stage of reccurrent bladder tumors. J. Urol., 118,
177-178, 1977.

10) Richie, J.P., Skinner, D.G. and Kaufman, J.J. : Radical cystectomy in carcinoma of the bladder : 16 years of experience. J. Urol., 113, 186-189, 1975.

11) Smith, J.A. Jr. and Whitmore, W.F. Jr. : Ragional lymph nodes metastasis from bladder cancer. J. Urol., 126, 591-593, 1981.

12) Skinner, D.G., Tift, J.P. and Kaufman, J.J. : High dose, short course preoperative radiation therapy and immediate single stage radical cystectomy with pelvic node dissection in the management of bladder cancer. J. Urol., 127, 671-674, 1982.

（1985年 3 月23日受付） 